\title{
The bird hunting referendum in Malta
}

\section{Michael Briguglio}

To cite this article: Michael Briguglio (2015) The bird hunting referendum in Malta, Environmental Politics, 24:5, 835-839, DOI: 10.1080/09644016.2015.1055880

To link to this article: http://dx.doi.org/10.1080/09644016.2015.1055880

册 Published online: 15 Jun 2015.

Submit your article to this journal 정

III Article views: 176

Q View related articles $₫$

View Crossmark data $־$ 


\title{
PROFILE
}

\section{The bird hunting referendum in Malta}

\author{
Michael Briguglio* \\ Department of Sociology, University of Malta, Msida, Malta
}

\section{Introduction}

Environmental NGOs (ENGOs) have an important role in the implementation of EU policy. They use links with European institutions to promote their grievances, particularly when they are unsatisfied with results of lobbying at a national level on matters covered by EU legislation. The Wild Birds Directive is a case in point. This piece of legislation has conservationist aims that are shared by ENGOs such as Birdlife International, which is active in all EU member states. The European Commission has taken legal action against Malta, Cyprus, Spain, Italy, and Austria for violating this Directive.

However, environmental issues linked to EU legislation have a strong national dimension. The case of bird hunting in Malta during spring is a good example. The issue has been the subject of intense political controversy and lobbying, and despite a decision by the European Court of Justice, it remained unresolved at a national level. The issue eventually escalated to a national legally binding referendum, held on 11 April 2015. Turnout for the referendum was $75 \%$, and the 'Yes' movement, which campaigned in favour of hunting in spring, emerged victorious, winning $50.4 \%$ of the vote, a mere 2220 vote advantage over the 'No' movement.

\section{The Maltese political context}

Politics in Malta is dominated by the Labour Party and the Nationalist Party, which have been described as catch-all parties with strong social networks and modern media apparatuses, acting like total institutions. The political landscape is, however, moving towards multifocal power and multilevel governance (Baldacchino 2014), especially under the impact of EU accession, local council governance, and the rise of civil society.

A small Green Party - Alternattiva Demokratika (AD) - was established in 1989 and has managed to elect a small number of local councillors, though it has not achieved national or European parliamentary representation. AD has,

\footnotetext{
*Email: michael.briguglio@um.edu.mt
} 
however, been very visible in civil society and has often acted as catalyst on various environmental and civil rights issues.

ENGOs have been active in Malta since the 1960s. The first ENGOs were conservationist, followed by the establishment of a variety of ENGOs from the 1980s onwards. Main issues highlighted included development of land, hunting and trapping of birds, and, to a lesser extent, climate change, waste management, and sustainable development.

ENGOs experienced mixed results in various campaigns and, following Malta's EU accession, used the EU as a gateway for empowerment on certain issues. However this process was uneven, depending on the issue at stake and type of ENGO (Briguglio 2010). For example, on development of land, EU accession had limited impact. Malta's climate change policies, on the other hand, were very much influenced by EU accession.

Within such a context, the bird hunting issue has been prominent in Maltese politics since the mid-1990s. EU accession raised the profile of the issue.

\section{The referendum campaign}

In the early 1990s, the Nationalist government introduced measures to curb hunting, which were met by fierce resistance by hunters. The Labour opposition exploited this opportunity and reached an agreement with hunters' representatives, to such an extent that the Federation of Hunters, Trappers and Conservationists directed its members not to vote Nationalist in the upcoming general election, which was won by Labour.

Labour's rule was short-lived as it had to call a snap election in 1998, which was won by the Nationalist Party. By then, the pro-EU membership Nationalist Party had made an agreement with hunters and trappers, promising that EU legislation would not have a negative impact on their pastime.

Before Malta joined the EU in 2004, the Labour Party opposed membership, and hunting was one of the issues because the EC Wild Birds Directive prohibits hunting in spring. Following another Nationalist electoral victory and Malta's EU accession, Malta adopted the Birds Directive in 2006. Subsequently the European Commission announced that it would take legal action against Malta because of continued hunting of birds in spring.

Spring hunting seasons were not opened in 2008 and 2009, and when the European Court of Justice decided on the issue, it announced that the Maltese government's authorisation of spring hunting of quail and turtle doves from 2004 to 2007 meant that Malta failed to comply with the Birds Directive. However, it also noted that hunting for quail and turtle doves in autumn was not a satisfactory solution (Briguglio 2014). The Nationalist government subsequently opened spring hunting seasons as from 2010, allowing the hunting of turtle doves and quail under strict regulations.

In 2013 the Labour Party won the general election and promised more concessions to hunters. Amidst the disenchantment of Malta's environmental 
movement, a coalition of ENGOs (including Birdlife Malta) and the Green Party successfully gathered enough signatures to call a legally binding abrogative national referendum on the matter. They were supported by the independent media and various public personalities. During the referendum campaign they emphasised the legality of the Birds Directive, the importance of migratory bird conservation in spring, and the public's right to access the countryside.

The pro-hunting lobby minimised the impact of hunting on bird populations and argued that the ruling of the European Court of Justice permitted hunting in spring under strict conditions. The respective leaders of the Labour and Nationalist Parties - Joseph Muscat and Simon Busuttil - said that they would vote 'Yes' in the referendum, though their parties did not adopt official stands on the matter.

Surveys carried out weeks before the referendum showed that the 'No' camp was in the lead. However, some days before the referendum - which coincided with local council elections in half of Malta's localities - Prime Minister Joseph Muscat made some public remarks in favour of the 'Yes' vote, which were interpreted by many as assisting the pro-hunting campaign. Muscat's popularity at national level and his closeness to the hunting lobby were used strategically, particularly during a speech he made in Malta's sister island Gozo, which hosts a sizeable number of hunters. It was evident that the Prime Minister and the Labour Party aimed to mobilise voters to support the hunting lobby and to show that Labour is the party that defends their interests. By contrast, the Nationalist Party and its leader Simon Busuttil were not particularly active on the hunting referendum. According to pre-referendum surveys, pro-Nationalist voters were shown to be more likely to support the 'No' movement than were pro-Labour voters.

Eventually, the 'Yes' camp emerged victorious. Voter turnout was higher in districts that favoured the pro-hunting campaign. Following the result, Prime Minister Muscat said that hunters have a final chance to preserve their pastime, and declared that the subsequent spring hunting season would open on turtle dove and quail (Sansone 2015). However, following a number of widely reported hunting illegalities and the punishment of offenders, Muscat declared the 2015 season closed three days before it was due to close.

\section{Interpreting the referendum outcome}

The impacts of the Referendum were of several kinds - sensitising, procedural, structural, and substantive. Both 'Yes' and 'No' camps were successful in terms of sensitising impacts. They raised public awareness of their grievances and claims and were highly visible in the press, public campaigns, and in influence on different political party agendas. Hunters were constantly on the agenda of the major political parties. For the environmental movement, sensitisation was successful at the level of EU institutions such as the Commission and Parliament, which supported its claims. 
Both camps achieved procedural and structural impacts. When Malta joined the EU, a window of opportunity was created for ENGOs and the Green Party to lobby at European level, especially through Birdlife and the Green group in the European Parliament. ENGOs were also officially consulted by the European Commission and Parliament. On the other hand, hunters were supported by their European counterpart (FACE) and by some MEPs from different parties, including all Maltese MEPs - who formed part of the Popular Party and the Socialist group (Briguglio 2014). State and EU funding was available for hunters and environmentalist organisations, and the latter also managed nature conservations sites, which often formed part of EU programmes. Monitoring camps were created by Maltese and European ENGOs.

In the meantime the Maltese government created an official consultative committee, Ornis, which had representatives from both camps. This did not result in uncritical co-option; both Birdlife and the Hunters' Federation remained antagonistic to governments when they deemed it appropriate.

The ultimate substantive impact was the referendum victory of the 'Yes' movement. Judging by voter turnout in different districts, it seemed more capable of mobilising the 'Yes' vote, also with a little help from Prime Minister Muscat's speech in Gozo at the peak of the campaign. Other substantive impacts could have been obtained prior to the referendum, especially for environmentalists. Indeed, they believed that the Birds Directive was enough to stop hunting of birds in spring, but enforcement against illegal hunting was weak and governments were criticised for under-reporting the numbers of birds killed to the EU. Besides, the European Court of Justice ruling was interpreted differently by hunters and environmentalists (Briguglio 2014). This put the ball back in the court of Maltese politics, to the dismay of environmentalists.

The hunting issue is likely to remain prominent in Maltese environmental politics. Arguments related to conservation, illegalities, and other matters will keep arising. The environmentalist movement may be disappointed with the referendum result, but it succeeded in mobilising almost half of Malta's voters despite lacking support from the two main political parties. The efforts of Malta's environmental movement might pay off in future campaigns. Substantive impacts in some specific environmental campaigns were achieved in the past, and Malta does not lack potential mobilising environmental issues. The sensitising impacts achieved through the hunting referendum point in this direction. Within a European context, the Malta referendum shows the importance of the national political dimension of environmental issues even when they are covered by clear EU legislation.

\section{Disclosure statement}

No potential conflict of interest was reported by the author. 


\section{References}

Baldacchino, G., 2014. Malta transformed by multi-level governance: more than just an outcome of Europeanization. Malta, Institute of European Studies. Available from: http://www.um.edu.mt/_data/assets/pdf_file/0019/228151/Godfrey_Baldacchino final.pdf [Accessed 5 May 2015].

Briguglio, M., 2010. Are ENGOs empowered through EU accession? The case of Maltese ENGOs. International Journal of Green Economics, 4 (3), 262-274.

Briguglio, M., 2014. Bird hunting in European Malta: a case of ENGO empowerment? In: L. Leonard and S. Buryn Kedzior, eds. Occupy the earth: global environmental movements. Bingley: Emerald, 295-324.

Sansone, K., 2015. 2,220 votes give hunters their referendum victory. Available from http://www.timesofmalta.com/articles/view/20150413/local/2220-votes-give-hunterstheir-referendum-victory.563716 [Accessed 5 May 2015]. 